\title{
CRUZAMENTO DO SOCIAL E DO AMBIENTAL NA “CONSTRUÇÃO” DE CHICO BUARQUE
}

\section{CHICO BUARQUE'S “CONSTRUCÃO" - A CROSS-ANALYSIS FROM A SOCIAL AND ENVIRONMENTAL POINT OF VIEW

\author{
CRUCE DE LO SOCIAL Y DE LO AMBIENTAL EN "CONSTRUCCIÓN" \\ DE CHICO BUARQUE.
}

Marco Pais Neves dos SANTOS

Resumo: A música "Construção" de Chico Buarque, editada pela Polygram em 1971, em São Paulo, difundiu habilmente a ausência de escrúpulos e a falta de dignidade a que era votado o ser humano dentro do seu próprio Estado, tendo ficado conhecida como uma bandeira de luta política contra a Ditadura Militar no Brasil. No entanto, sem ignorar o facto político, procuramos neste ensaio dilatar as possibilidades de compreensão do texto, analisando-o na perspetiva das questões ambientais e da ecologização das relações sociais. Mostramos que se trata de uma música que utiliza símbolos sonoros polissémicos e plurivalentes, comportando portanto uma linguagem rica em significações e conotações, que permite fazer uma interpretação das questões sociais da época, conotando-as com as questões ambientais e de ecologização das relações sociais atuais, porque apresentam o mesmo nível de significância. Concluímos que, mesmo ao fim de 40 anos, a letra conserva toda a sua atualidade e tem conotações diretas com questões prementes da sociedade atual, onde se procura a construção de uma mudança rumo à sustentabilidade.

Palavra-chave: Poder Político; Equilíbrio Social; Música de Intervenção.

Abstract: Chico Buarque's song named "Construção" (Construction), released by Polygram in 1971, in São Paulo, ingeniously exposed the lack of scruples and the indignity the human being was submitted to in his own State and became famous as a symbol of political fight against the Military Dictatorship in Brazil. However, without ignoring the political fact, in this paper we endeavour to enlarge the possibilities of understanding the text, by including in our analysis the environmental and ecological issues of social relations. We show that this song uses polysemic and polyvalent sound symbols, thus allowing for a very rich language in terms of meaning and connotations, which enables an interpretation of the social issues at the time, by connoting them with the environmental and ecological issues of modern social relations, because they have the same level of significance. We conclude that, even after forty years, the lyrics remain highly topical and have direct connotations with the urgent issues of today's society, where the construction of a change towards sustainability is sought.

Keywords: Political Power; Social Balance; Music Intervention.

Resumen: El tema "Construcción" de Chico Buarque, editado por Polygram en 1971 en São Paulo, ha difundido hábilmente la ausencia de escrúpulos y la falta de dignidad a que era sometido el ser humano en su propio Estado, habiendo sido conocido como bandera de lucha política contra la Dictadura Militar en Brasil. Sin embargo, sin dejar de lado el hecho político, intentamos en este ensayo ensanchar las posibilidades de comprensión del texto, analizándolo desde la perspectiva de los problemas ambientales y de la ecologización de las relaciones sociales. Mostramos que se trata de una canción que utiliza símbolos sonoros polisémicos y multivalentes, que comprende, por lo tanto, un lenguaje rico en significados y connotaciones, lo que permite hacer una interpretación de las cuestiones sociales de la época, que conecta con los problemas ambientales y sociales actuales, debido a que presentan el mismo nivel de importancia. Llegamos a la conclusión de que, incluso después de 40 años, la letra mantiene toda su actualidad y tiene connotaciones directas con cuestiones acuciantes de la sociedad actual, que busca la construcción de un cambio hacia la sostenibilidad. Palabras-Clave: Poder político; Equilibrio social; Canción protesta.

\footnotetext{
${ }^{1}$ Licenciado em História e Geografia e Planeamento Regional, Universidade Nova de Lisboa. Mestrado em Cidadania Ambiental e Participação, Universidade Aberta. Doutorando em Desenvolvimento Social e Sustentabilidade, Universidade Aberta. Direção de Qualificação e Licenciamento, Instituto dos Mercados Públicos, do Imobiliário e da Construção, I.P. E-Mail: marco.santos@impic.pt.
} 


\section{INTRODUÇÃO}

A arte tem constituído ao longo do tempo uma das formas mais utilizadas de contestação e luta contra as forças opressivas, os desequilíbrios sociais e os regimes ditatoriais. Dentro do universo da arte, destaca-se a música, uma poderosa ferramenta de comunicação que tem boas hipóteses de chegar à maior parte da população (se não for censurada), tornando-se, portanto, um importante veículo no processo de difusão e proliferação de conhecimento e mensagens.

Durante a Ditadura Militar do Brasil, Chico Buarque foi exímio em retratar através da arte e, sobretudo, através da música, a vivência social e política, refletindo a imagem de um país socialmente dilacerado pelo poder ditatorial. A sua luta foi inteligente e sagaz, e permitiu a consciencialização externa da realidade de um povo que vivia oprimido e era desrespeitado e fortemente reprimido. Do conjunto da sua extensa obra, que só na música conta com mais de três centenas de títulos, surge a música "Construção", editada em 1971, da qual foi autor e intérprete.

Esta canção é primeiramente uma bandeira a favor da luta política contra a ditadura militar, ainda que o autor lhe dê outras interpretações, como veremos ao longo do artigo. No entanto, as nossas possibilidades de compreensão da letra estendem-se para além do contexto político, seguramente até às questões ambientais e de ecologização das relações sociais e, nesse sentido, apesar de volvidos 40 anos, ainda faz toda a diferença na sociedade atual e merece a nossa reflexão. 0 significado inicial está lá, na letra, mas a beleza das figuras usadas consegue adaptar-se. A genialidade de Chico Buarque está aí, na sua capacidade de produzir música que continua a ser ouvida e interpretada de formas diferentes, durante anos a fio, tanto em termos individuais como coletivos, independentemente da faixa etária, classe social ou espaço geográfico, como um processo mnemónico de constante (re)conotação.

$\mathrm{Na}$ "Construção" encontramos um Homem "em construção", o que nos remete para a necessidade de construir uma sociedade mais responsável, a vários níveis mas sobretudo do ponto de vista ético e socio-ambiental, com comportamentos, valores e princípios adequados à salvaguarda do ambiente. É nesse sentido que neste ensaio procuramos relacionar a vertente social com a vertente ambiental na canção "Construção", e simultaneamente refletir, de forma integrada, sobre a ideia central da letra: o facto de não serem só as ações a ter importância mas também o modo como as realizamos.

\section{A MÚSICA E O SEU CRIADOR}

A arte não vive apenas da intenção do seu criador, até porque a sua definição alterna no tempo e no espaço (nas várias culturas humanas). Também a música, enquanto subárea da arte, é uma construção cultural variável. A comunicação artística musical, que utiliza sinais sonoros, polissémicos e plurivalentes, ao contrário das linguagens mais técnicas (ex. académica), ou das mais populares (ex. quotidiana), não é informativa ou explicativa, é plurissignificativa, ou seja, é especialmente rica em 
significações e conotações. Como tal, a partir do momento em que uma música é divulgada, o forte poder sugestivo que encerra em si revelar-se-á tanto mais intenso quanto maior for a capacidade de interpretação, de associação e de inter-relação simbólica por parte de quem a degustar. Por isso mesmo, toda a música gera sentimentos diversos e está aberta a novas e diversas interpretações, como acontece sobretudo com as músicas de Chico Buarque, todas elas muito humanizantes. No entanto, por mais interpretações de que as músicas possam ser alvo, a título individual ou coletivo, no mesmo momento ou em épocas diferentes, em circunstâncias iguais ou diferentes, no mesmo espaço ou em locais distintos, elas não se anulam mutuamente e todas têm de ser interpretadas nos seus contextos, para que delas se possa extrair o seu sentido; elas são simplesmente complementares. Como refere Max Weber, no âmbito das bases epistemológicas do "Método Compreensivo", qualquer realidade social e histórica tem aspetos incomensuráveis, muito complexos, muito dinâmicos e, como tal, o conhecimento é sempre frágil, pois existe sempre outro conhecimento que se pode fazer com base nos mesmos elementos, ou seja, o conhecimento obtido nunca é o último (absoluto), é sempre a parte, muito pequena, de um processo em evolução (Weber, 1996).

A música "Construção" de Chico Buarque é equiparável, em Portugal, às músicas "E Depois do Adeus", de José Nisa, e "Grândola, Vila Morena", de José Afonso, que ficaram para sempre como as músicas mensageiras da Revolução de 25 de Abril de 1974, e também se equipara à música "Liberdade", do álbum "À Queima-roupa" de Sérgio Godinho, que surgiu logo após a Revolução de 25 de Abril de 1974. De forma comparativa, ao fim de cerca de 40 anos, a música "Grândola, Vila Morena", de José Afonso, que teve uma grande importância na História do Portugal contemporâneo, é agora muito utilizada como forma de protesto contra as políticas económicas impostas pelo governo português, sob a liderança de Pedro Passos Coelho, e pela "troika", constituída pela Comissão Europeia (CE), Banco Central Europeu (BCE) e Fundo Monetário Internacional (FMI). Este regresso da antiga canção "Grândola, Vila Morena" para marcar presença em numerosas manifestações de ordem social mas de origem, estrutura ou finalidade diversas, sobretudo ao longo do mês de fevereiro de 2013, remete para uma revalorização da música, agora como hino de revolta e contestação popular, por parte de quem vive uma situação de emergência económica e financeira, e também uma situação de emergência social e, consequentemente, ambiental, lutando contra a fome, o desemprego, o excesso de impostos, a redução de salários e a perda de direitos, o despejo por falta de pagamento do crédito à habitação, a destruição do Estado Social, a segmentação social, a fraude económica, a corrupção política e a promiscuidade e/ou submissão interesseira entre poder político e poder económico.

À semelhança da música "Construção", cujos múltiplos sentidos interpretativos não têm fonteiras geográficas, também a "Grândola, Vila Morena" de José Afonso foi cantada em Madrid, na Puerta del Sol, pelo Movimento 15-M, em 16 de fevereiro de 2013.

\section{ALGUNS ELEMENTOS BIOGRÁFICOS DE CHICO BUARQUE}

Francisco Buarque de Hollanda, mais conhecido por Chico Buarque, afamado compositor, dramaturgo e cantor brasileiro, filho do historiador e sociólogo Sérgio Buarque de Holanda (autor do clássico "Raízes do Brasil”) e da pianista Maria Amélia Cesário Alvim, nasceu no Rio de Janeiro em 1944. 
Em 1963, ingressou na Faculdade de Arquitetura e Urbanismo da Universidade de São Paulo, curso que haveria de abandonar três anos mais tarde, motivado pelo clima de repressão, para dar início à sua carreira musical. No entanto, ainda na faculdade, tocou e dançou no grupo "Sambafo", que tinha constituído com alguns dos seus colegas (Meneses, 1980, 1982).

Chico Buarque adquiriu notoriedade quando venceu, com a canção “A Banda" (1966), o Festival de Música Popular Brasileira. Seguiram-se dezenas de outras músicas, de grande repercussão, onde o lirismo, a sensualidade e a preocupação social eram as principais vertentes, e onde está bem patente o poder quase mágico das suas palavras. Para o teatro escreveu, entre outras, "Roda-viva" (1967) e "Ópera do Malandro" (1979) (Fernandes, 2004, p. 25-26).

A sua obra musical "confunde-se" com poesia, de grande qualidade, virtuosidade e universalidade, ainda que inicialmente tenha sido criticado por abusar do lirismo e da nostalgia, e rotulado de conservador e reacionário. Só depois de lançar os dois primeiros romances de sucesso é que se esbateria a carga negativa subjacente à sua imagem criada pela comunicação social e seria atribuído valor poético à sua obra (Ridenti, 2000).

\section{ENQUADRAMENTO HISTÓRICO DA MÚSICA “CONSTRUÇÃO”}

Em 1964 iniciou-se a Ditadura Militar no Brasil. Apesar de o governo militar atuar de forma repressiva, tal como aconteceu em outros regimes autoritários, pode considerar-se que a repressão no Brasil era "moderada", na medida em que eram toleradas as manifestações de artistas e intelectuais de esquerda. Aliás, entre 1964 e 1969, em plena ditadura da Direita, houve uma relativa hegemonia cultural da esquerda no país, frase clássica de Roberto Schwarz, ainda que, em resposta, o governo militar tivesse aprovado o Decreto do AI-5³, em 13 de dezembro de 1968 (Fernandes, 2004, p. 32). Este diploma instituía um mecanismo autoritário para controlar a oposição e mitigar a contestação, até porque o regime autoritário preservou algumas heranças, ou pelo menos não atacou tão veementemente o samba, que mimetizava um forte sentimento de identidade nacional ${ }^{4}$.

Em janeiro de 1969, no seio desta conjuntura, Chico Buarque se autoexilou na Itália, onde permaneceu exilado durante um ano, fazendo alguns espetáculos (ex. com Toquinho). Regressou ao Brasil em março de 1970, mas a censura militar obrigou-o a adotar um pseudónimo para poder continuar a editar as suas músicas. Ainda assim, passou a ser um dos artistas mais perseguidos pela censura e na primeira metade da década de 70, [foi] várias vezes intimado a comparecer ao Exército e à Polícia Federal (Fernandes, 2004, p. 33).

A conjuntura mundial não era muito favorável. Vivia-se uma época conturbada da história da humanidade que colaborava para este espírito crítico de Chico Buarque: os regimes ditatoriais em alguns países (ex. Chile e Portugal); a violência policial noutros (ex. Alemanha, França, Itália e Grécia);

3 O AI-5 foi o principal instrumento de arbitragem da ditadura militar (não democrático), que permitia reprimir, censurar, torturar e perseguir opositores ao regime.

4 O Samba é um género musical de origem africana, uma das principais manifestações culturais populares brasileiras, que germinou entre os mestiços. Foi com o apoio do Estado Novo (Getúlio Vargas), e dos intelectuais da sociedade brasileira, e beneficiando do sucesso do mito da democracia racial (Skidmore, 1989), que passou de canção popular do Rio de Janeiro a canção nacional, portanto, a elemento de Identidade Nacional (Viana, 2004). O samba está para os brasileiros como o fado para os portugueses, já que em ambos os países governos autoritários transformaram uma realidade musical nascida nas classes populares numa forma musical de identidade nacional (Almeida, 1995; Viana, 2004). 
a Guerra do Vietname que se arrastava desde 1959; e, entre outros acontecimentos mais recentes, o "Maio de 68", uma greve geral com proporções revolucionárias que se instalou em França. Mas também se assistiu a acontecimentos positivos, como a chegada do Homem à Lua, ou mesmo o festival de Woodstock que marcou o auge da contracultura hippie com o famoso lema "make love, not war" $\mathrm{e}$ estava em sintonia com as esperanças utópicas dos anos 60 (Ridenti, 2000).

Nessa altura, na década de 70 do século XX, o Brasil estava mergulhado numa crise profunda, com grande instabilidade social, num ambiente de revolta, de indignação, de crispação, de estrangulamento cívico, de agonia social (ex. salários muito baixos, inflação muito alta e moeda sem valor) (Meneses, 1982), e a população encontrava-se carenciada, oprimida e sem condições mínimas de subsistência ("desnutrida", como se dizia à data). Como em qualquer governação ditatorial, a imprensa vivia sob censura e havia muitas denúncias de tortura, morte e desaparecimento de presos políticos. As guerrilhas de esquerda (rurais e urbanas) eram eliminadas, e o poder reprimia pela força as manifestações populares. No entanto, os empréstimos e investimentos estrangeiros permitiram que este fosse também um período de grande crescimento económico, sobretudo entre as classes mais abastadas, devido ao aumento da atividade no setor da construção civil e obras públicas, ao aumento do consumo de bens e ao controlo da inflação (o milagre económico brasileiro). Esta situação gerou ainda maior segregação social e acentuou a desigualdade entre ricos e pobres. Para denunciar carências sociais, económicas e culturais, e a ausência de liberdade, Chico Buarque cria e interpreta a música "Construção", editada pela primeira vez em 1971, num LP com o mesmo nome (Fernandes, 2004).

Esta canção retrata a vida e a morte de um trabalhador da construção civil, o setor que mais se expandiu durante a governação militar, enfatizando disparidades, pobreza e injustiça social, reforçando a irrelevância da classe operária numa sociedade consumista, comandada por valores materiais e não morais, o que também remete para a insustentabilidade das relações entre pessoas, no meio em que vivem, tudo isto com a cumplicidade do poder político e económico (Kutting, 2004). É, portanto, uma crítica à (des)ecologização das relações humanas e sociais, e uma bandeira de luta política contra a ditadura militar brasileira (Meneses, 1982, p.73). Esta visão tem enquadramento na análise de Luís Sá, que dá razão a Maquiavel, pelo menos num ponto, em relação ao facto de não existirem poderes perfeitos, nem homens ou mulheres perfeitos, o que permite o aparecimento de "válvulas de escape" na política, ou seja, mecanismos de defesa, controlo e combate ao abuso de poder (Sá, 1999, p.13-14).

Julgamos que a composição de canções de crítica social foi o mecanismo encontrado por Chico Buarque para, fora do sistema político formal de controlo, combater o poder militar, sobretudo depois da implementação do AI-5 (apesar de inicialmente as suas canções evidenciarem sensibilidade social, sobressaía em primeiro plano alguma nostalgia) (Meneses, 1982, p.48). No entanto, ele próprio não se considera um cantor/poeta de intervenção ${ }^{5}$ (Meneses, 1980) e justifica isso com o facto de sempre ter trabalhado da mesma forma: antes, durante e depois da ditadura militar. Considera que as suas letras retratavam a vida, o quotidiano, de forma jornalística e não com fundamento político. 
Segundo ele, numa conjuntura política, social e económica tão delicada, era normal que as suas letras refletissem essas tendências. Advoga a favor desta hipótese o facto de o seu trabalho refletir em muito as leituras dos periódicos da altura (Meneses, 1980, p.3), e, como ele próprio diz: o bom cabrito berra (Martins, 2005, p.3).

É possível que Chico Buarque tenha criado músicas de protesto contra o poder dominante sem se rever nesse registo, e que isso seja uma consequência do momento. No entanto, depois de se ter autoexilado em Itália, com receio dos militares, e depois de ter regressado ao Brasil sob pseudónimo para poder continuar a editar as suas músicas, já nos parece "estranho" que, apesar de perseguido pelo Exército e pela Polícia Federal, continuasse a manter nas suas canções o registo provocatório ao regime. Se, eventualmente, não era sua intenção fazer oposição ao regime militar, então não teria de provocar de forma reiterada esse mesmo regime, com todas as consequências que daí lhe advieram. Parece óbvio que o quotidiano poderia ser retratado de muitas outras perspetivas e que a sátira não era um fim em si mesma, mas uma forma de atingir um fim maior, a crítica política (a "válvula de escape" referida por Sá, 1999, p.13-14).

\section{INTERPRETAÇÃO DA MÚSICA “CONSTRUÇÃO”: PERTINÊNCIA SOCIAL E AMBIENTAL}

A letra da canção "Construção" permite várias interpretações, o que, aliás, motivou críticas ao autor, que o acusam de ser alienante, porque as suas mensagens são bastante subliminares, não acessíveis para todos. Fora deste debate, a primeira interpretação possível é que o compositor procura demonstrar uma sociedade em dismonia, o que radica em desordem cívica e ilegalidade, e como tal invoca os seus responsáveis: governo ditatorial, serviçais do governo ditatorial, e cidadãos. Em termos macro, considerando esta interpretação, os governantes eram culpados pelas políticas de repressão e por menosprezarem a sociedade (Subiu a construção como se fosse máquina; Seus olhos embotados de cimento e lágrima); os serviçais do governo ditatorial, clássicos intermediários entre os detentores dos meios de produção e os trabalhadores (no sentido conferido por Pierre Bourdieu), por prestarem vassalagem ao poder, em quase total subserviência, colaborando na repressão do povo (Agonizou no meio do passeio público; Morreu na contramão atrapalhando o tráfego); e os cidadãos, por estarem em condição de estagnação, sem atitude, sem ação e reação, movendo-se com desânimo e apatia, mostrando inércia e moribundez (Sentou pra descansar como se fosse sábado; Sentou pra descansar como se fosse um príncipe; E se acabou no chão feito um pacote tímido).

Ao poder da classe dominante, combatida por alguns, uma grande franja da sociedade resignava-se. Ora, é hoje fundamental alterar tal atitude, tanto nas questões sociais como ambientais, promovendo uma cultura de cidadania e de participação cívica ativa. Ter atitude significa ser responsável pelo que se faz e, principalmente, pelo que não se faz. O ser humano é um ser livre, mas, se não exercer a plena cidadania, não pode exercer a sua própria liberdade. Falta-nos a sintonia com o meio, a consciência das nossas fragilidades e a convicção das nossas capacidades, mas sobra-nos o comodismo e principalmente o egoísmo.

Após uma interpretação transversal/generalista, vamos desconstruir e interpretar a letra 
da "Construção" de forma pormenorizada, percorrendo um caminho construtivo, colocando no mesmo patamar a sustentabilidade social e ecológica, sem nunca perder de vista o que refere Adriano Senkevics (2007): resumir o trabalho do Chico devia ser considerado uma infração moral.

As três estrofes em análise são muito semelhantes. Todas começam em "amou" e terminam em "morreu", transmitindo a ideia de que tudo tem um princípio e um fim, e que depende de nós próprios alterarmos esse fim, tornando-o melhor. Registe-se o facto de a última palavra do último verso de cada estrofe ser sempre uma palavra esdrúxula.

A letra apresenta um carácter cíclico e comparativo, e demostra a importância dos adjetivos no contexto, isto é, as ações que apresenta uma e outra vez são as mesmas, mas a maneira de as realizar é diferente, como se pode ver a seguir, através de um exercício simples, em que comparamos os sete versos da terceira estrofe com os sete versos equivalentes, em termos de informação, constantes nas duas estrofes anteriores:

\begin{tabular}{|c|c|c|}
\hline Fragmento $1^{\text {a }}$ Estrofe & Fragmento $2^{a}$ Estrofe & $3^{a}$ Estrofe \\
\hline $\begin{array}{l}\text { Amou daquela vez } \\
\text { como se fosse a última } \\
\text { Beijou sua mulher como } \\
\text { se fosse a última } \\
\text { Ergueu no patamar } \\
\text { quatro paredes sólidas } \\
\text { Sentou pra descansar } \\
\text { como se fosse sábado } \\
\text { E flutuou no ar como se } \\
\text { fosse um pássaro } \\
\text { E se acabou no chão } \\
\text { feito um pacote flácido } \\
\text { Morreu na contramão } \\
\text { atrapalhando o tráfego }\end{array}$ & $\begin{array}{l}\text { Amou daquela vez como } \\
\text { se fosse o último } \\
\text { Beijou sua mulher como } \\
\text { se fosse a única } \\
\text { Ergueu no patamar } \\
\text { quatro paredes mágicas } \\
\text { Sentou pra descansar } \\
\text { como se fosse um } \\
\text { príncipe } \\
\text { E flutuou no ar como se } \\
\text { fosse sábado } \\
\text { E se acabou no chão } \\
\text { feito um pacote tímido } \\
\text { Morreu na contramão } \\
\text { atrapalhando o público }\end{array}$ & $\begin{array}{l}\text { Amou daquela vez como } \\
\text { se fosse máquina } \\
\text { Beijou sua mulher como } \\
\text { se fosse lógico } \\
\text { Ergueu no patamar } \\
\text { quatro paredes flácidas } \\
\text { Sentou pra descansar } \\
\text { como se fosse um } \\
\text { pássaro } \\
\text { E flutuou no ar como se } \\
\text { fosse um príncipe } \\
\text { E se acabou no chão } \\
\text { feito um pacote bêbado } \\
\text { Morreu na contramão } \\
\text { atrapalhando o sábado }\end{array}$ \\
\hline
\end{tabular}

Os versos assim dispostos permitem refletir sobre o facto de não serem só as nossas ações que têm importância, mas também o modo com as executamos, o que tanto é válido para as questões sociais como para as ambientais. Aliás, em relação ao comportamento humano, às nossas ações socioambientais, mais importante do que tornar os nossos comportamentos adequados, só mesmo refundálos em valores e princípios adequados, capazes de garantir de forma sustentada o futuro da sociedade. É essa pró-atividade que faltava aos cidadãos, de acordo com a crítica que lhes é feita por Chico Buarque, e que ainda continua a faltar, isto claro, na nossa interpretação, que tem subjacente a ideia sintetizada no quadro a seguir: 


\begin{tabular}{|l|l|lc|}
\hline Esta empresa não contamina, & Esta empresa não contamina porque & Esta empresa não contamina porque \\
porque consideramos ser nosso & pagamos multa se o fizer. & vendemos & mais \\
dever contribuir para um ambiente & & não \\
mais saudável. & & & \\
\hline
\end{tabular}

A letra da música remete para um homem que trabalha na construção civil e que tem uma família de quem gosta (mulher e filhos). Pode interpretar-se que anda desanimado (beija como se fosse a última vez) e que pertence a um estrato social baixo (anda bêbado, tem muitos filhos e tem um trabalho cansativo).

A alternância na velocidade a que caminha - devagar quando atravessa a rua e depressa quando sobe à obra - remete para o particularismo social que se viveu durante a ditadura, sempre a potenciar a padronização e mecanização da sociedade, ou também pode remeter para um sentimento de inferioridade por pertença a um estrato social mais baixo.

A alimentação é um pouco pobre. Isso pode indicar que se trata de um homem com uma rotina muito acentuada, que não tem tempo para fazer uma alimentação cuidada/diferenciada, que possivelmente realiza um intenso trabalho braçal, e por isso o pequeno descanso da hora de almoço tem um sabor especial, como se de um sábado se tratasse (final de semana). A indicação de que bebeu como se fosse um náufrago, ou seja, bebeu até ficar bêbado, remete para a existência de traumas ou para a pertença a uma classe social baixa, o que é reforçado pelo verso que refere as lágrimas e o cimento nos seus olhos, pois também remete para a dureza da vida e para o sofrimento da condição social, possivelmente agravada pela rigidez e opressão política.

o homem estava a trabalhar alcoolizado e terá sido o álcool que potenciou o descuido que originou a queda em altura na obra e, consequentemente, a sua morte. Isto remete para uma sociedade pouco deliberativa, pouco participativa, muito isolada e socialmente pouco evoluída, que valoriza os deveres e não os direitos (ex. ausência de regras de segurança e higiene no trabalho), e onde não importam os meios mas sim os fins; uma estrutura social característica de uma ditadura militar. Segundo Chico Buarque, terá voado como um pássaro e caído com estrondo no chão, de tal forma que o seu corpo ficou flácido. Voar simboliza liberdade. Aliás, desde sempre uma inspiração humana, movida pelo desejo de transcendência. Então, será que o humilde operário conseguiu inconscientemente a liberdade? De um mundo cruel e desumano, acabou por ter uma morte gloriosa? A morte é sempre negativa, mas podemos considerar que sim, desde logo se a compreendermos como a "válvula de escape" (a uma vida dolorosa), ou seja, foi a forma encontrada por Chico Buarque para puxar pelo saudável no meio da decadência e da destruição.

Perdeu-se uma vida, ficou uma família fragmentada, em sofrimento, mas o que mais preocupou as pessoas que circulavam no passeio foi o estorvo que o cadáver causou. Nunca será possível viver num mundo sustentável enquanto os cidadãos não compartilharem das mesmas preocupações, não lutarem pelos mesmos objetivos e não possuírem uma consciência coletiva, mesmo em períodos de governação política autoritária, tal como se pode ler em Unamuno (1989, p. 218), que escalpeliza ao detalhe o sentido da existência humana ao dizer: a minha conduta tem de ser a melhor prova, a prova moral do meu desejo supremo.

A indiferença da população perante o acidente é reveladora de uma frieza extrema entre 
indivíduos da mesma espécie (humana), e demonstra que o humilde trabalhador era invisível aos olhos de uma sociedade claramente dominada pelo capitalismo industrial, que negligenciava a necessária ecologização das relações sociais. Este é um bom exemplo para se perceber que comportamento gera comportamento (Goleman, 1996), que todos precisamos de viver em sociedade, partilhando, e que é o indivíduo o gestor da evolução humana (Goleman, 2006).

No entanto, a palavra "partilha" não faz parte da canção e, apesar de uma grande parte da população viver carenciada, oprimida, com fome e sem condições mínimas de subsistência, podemos perceber que, no oposto, existia quem vivesse confortavelmente, recebendo influências de um forte marketing comercial (na canção "Televisão", Chico Buarque critica os meios de comunicação). O marketing transmitia ao consumidor a vontade de "comprar/consumir", aproveitando o facto de esse ser o alicerce da felicidade e do bem-estar das sociedades modernas. Após dilatado, o paradigma consumista passou a servir de régua para definir a posição social dos indivíduos (ostentar riqueza material é sinónimo de posição social) (Baudrillard, 2005). A classe de operários, que não tinha acesso a estes recursos, sentia-se relegada na sua posição social. Por isso mesmo, devemos também considerar a equidade, tanto nas relações sociais e na distribuição de riqueza, como na relação consumo vs disponibilidade (de recursos naturais).

Tal como vem dizendo Goleman, primeiro com as teorias da inteligência emocional (1996) e da inteligência social (2006), onde enfatiza a necessidade de harmonizar sentimentos e pensamentos nas relações interpessoais (empatia social), e recentemente com a teoria da inteligência ecológica (2009), onde releva as consequências da demanda consumista e aponta a necessidade de uma classificação séria dos produtos considerados ecológicos, de forma a filtrar os "falsos produtos verdes", ensinando consumidores e produtores a avaliar de forma precisa o quão ecológicos eles realmente são nas suas atividades, é necessária e urgente uma revolução cívica (empatia ecológica). Esta alteração do paradigma vigente está nas mãos do consumidor responsável e “inteligente" (Goleman, 2009).

Importa salientar que, quando uma sociedade minimiza, ignora, exclui ou desvaloriza uma parte dos indivíduos ou toda uma classe social, tal como parece preconizar a letra da "Construção", está a potenciar o afloramento do debate moral sobre valores humanos, culturais, ecológicos e económicos, e abre espaço à instabilidade e à crítica social. As políticas para a sustentabilidade devem afastar comportamentos entrincheirados, elitistas, antissociais e anticolaboracionistas, objetivo tão importante como a necessidade de ecoalfabetizar, de passar à ação e de aplicar os conhecimentos das ciências ecológicas e a sabedoria da consciência ecológica às situações da vida, na sociedade e na cultura (Ribeiro, 2009).

E isso é possível: basta tomar como exemplo o trabalho de Michael K. Stone, editor sénior do Center for Ecoliteracy (organização presidida pelo carismático e prestigiado Fritjof Capra), que comporta um manancial de boas ideias, de inúmeras estratégias e estudos de caso (refere-se a escolas da América do Norte), projetados para apoiar os educadores e mostrar aos educandos que são parte integrante da natureza. Além disso, considerando que a educação para a sustentabilidade está em constante aperfeiçoamento, realça que essa deve acontecer em todo o lugar e não só nas escolas, ainda que, em relação a estas, a obra tenha efeitos de antídoto, demolindo por completo a ideia de que 
as instituições de ensino estão a falhar, ou de que é obvio que vão falhar, e mostrando que são muitos os casos de sucesso, onde os currículos escolares integram a educação para a sustentabilidade, de forma simples e extremamente inovadora, com significativos ganhos para o potencial dos alunos, que estão mais habilitados e são mais capazes, e para o planeta (Stone, 2009).

Analisando em pormenor a questão da morte, surgem várias ideias, mas será mais interessante ver como evoluem as referências de que é alvo nas três estrofes: na primeira, o autor refere a morte na contramão atrapalhando o tráfego, na segunda substitui o tráfego pelo público, e na terceira substitui este pelo sábado. Pode-se estabelecer um paralelismo entre a força das palavras e a crítica social, na medida em que esta se acentua com o evoluir da letra. Inicialmente o tráfego (mais materialista), depois o público (mais fechado em si mesmo), e por fim o sábado (força máxima da crítica porque é no sábado que as pessoas ditas normais passeiam, enquanto as invisíveis trabalham). Se compararmos esta análise com a ênfase que Chico Buarque imprime à letra quando a canta, percebemos que acentua o tom no penúltimo verso de cada estrofe, e no último verso, quando refere a morte, acentua a expressão de vazio, de perda, de desolação. De facto, apesar de cada indivíduo ser construtor da sua própria realidade, é fortemente influenciado pelo ambiente social, do grupo ou do espaço onde está inserido (Smith; Mackie, 1995), pelo que, entrando numa espiral de pessimismo, de fracasso, abdicando do viver e do saber, pressão a que estavam sujeitos os indivíduos e os grupos, nomeadamente os mais carenciados da sociedade, o fracasso fica a um passo.

Parece que o autor nos conta a história desde a vida até à morte em três fases: começa na juventude, passa pela idade adulta e acaba na velhice. Contudo, a forma como canta a música deslocase num percurso que parte do agradável (amor/família) para terminar no trágico (morte/desprezo). Este deslocamento do bom para o mau é comparável à rapidez com que o ser humano se desloca para o abismo, ao insistir em controlar e domesticar a natureza a seu bel-prazer (Moral; Walker, 2009).

Chico Buarque indica-nos que o homem era chefe de família e isso conferia-lhe poder, mas na sociedade ele era completamente invisível, desprezável ou substituível. O mesmo se aplica ao ser humano, que tem poder no local onde está inserido através das suas ações ou atitudes, mas no cômputo geral está submisso às forças da natureza, que inclusive podem deslocar a vida humana do agradável para o trágico (MoraL; Walker, 2009; Sassa; Canuti, 2009).

\section{REFLEXÃO FINAL}

Expomos neste artigo a nossa interpretação da canção "Construção", que naturalmente diverge da do próprio autor, podendo gerar controvérsia. Mas tudo isso é de somenos importância perante uma realidade: qualquer música, depois de editada, deixa de identificar e representar somente a intenção do seu autor e passa a ser interpretada e recriada pelo público que com ela se identifica e nela se revê, que a absorve e lhe atribui significado e simbologia, o que resulta numa diversidade de interpretações. Se é possível extrair da letra desta canção algo verdadeiramente importante, será a enunciação de que também a sociedade deve reconfigurar a sua consciência, alinhando-a com valores sustentáveis, ecológicos, pensando sempre no conjunto e não nos indivíduos de forma isolada (Goleman, 2009). 
Mais importante que o fim último da canção (música de intervenção), é a sua validade em qualquer momento histórico e político, porque identifica um problema social, à semelhança do que se pode referir em relação à visão extremamente crítica que Gil Vicente tinha da sociedade portuguesa, no século XVI, ou em relação à sátira do Padre António Vieira através do Sermão aos Peixes, no século XVII, que ainda não foram esquecidas e adquirem cada vez mais força na sociedade atual, em prol da cada vez maior diferença entre o que o poder proclama e o que o poder realmente faz (Sá, 1999, p.13).

O início do século XXI, fortemente marcado por problemas ambientais, financeiros e sociais, mostra-nos que o papel do opressor no futuro será certamente desempenhado pelas grandes empresas, na demanda pelo lucro a qualquer custo, ou pela ditadura das relações sociais. Mas a opressão é camuflada e ocorre com a conivência dos próprios cidadãos. Por comparação com a letra da obra "Construção", os gestos mecânicos e pouco humanistas representarão a sociedade de consumo, que também age mecanicamente, em busca da realização imediata e efémera dos desejos, tal como o pássaro e o príncipe da canção.

Para refrear a força das empresas defensoras do capitalismo neoliberal, não cumpridoras da responsabilidade empresarial (social e ambiental), para mitigar a vergonhosa promiscuidade entre o mundo político e o mundo económico, e para alterar o paradigma vigente na sociedade, passando de uma sociedade consumista e predatória para uma sociedade responsável e equilibrada, que defenda os desígnios do Desenvolvimento Sustentável, já defendidos no Relatório Brundtland (1987), o Homem atual terá de mudar a forma de ser e estar, terá de começar a construir, tijolo a tijolo, um mundo mais sustentável. Temos de ser nós próprios a pegar nos tijolos, como operários, e construir um mundo melhor. Tal como procurou mostrar Goleman, que consubstanciou em "Ecological Intelligence" atributos de obras anteriores, nomeadamente da "Social Intelligence", os indivíduos enquanto seres gregários carecem de alguns ingredientes na organização da vida social, como a empatia, a solidariedade, o estar em sintonia com o próximo, e a capacidade de nos colocarmos no lugar do outro (Rapport ${ }^{6}$ ), ingredientes que se mantêm fundamentais na relação com o ambiente natural. Com rigor, para Goleman existem duas formas de nos relacionarmos com os outros: uma primeira, maligna ("I and Thou" ou "Eu e Tu"), onde as pessoas são tratadas como objetos e não como pessoas; e uma segunda, benigna ("I-You" ou "Eu-Tu"), onde existem a afinidade e o respeito recíproco, inspiração que Goleman (2009) pretende ver inscrita na atitude humana perante a biosfera. Não restam dúvidas de que o individualismo e a indiferença, a exemplo da letra de Chico Buarque, levam ao isolamento, ao materialismo, à destruição sustentada e progressiva, e à não ecologização das relações sociais, portanto, não são solução.

O grito neste tempo será, ainda mais que na altura, uma ação, um gesto, um mudar de vida. Ao contrário do pedreiro referido por Chico Buarque, embora já não sejamos calados, a verdade é que nos resignámos a viver sob a pressão das necessidades que nós próprios criámos e que reiteradamente procuramos justificar como sendo básicas à nossa existência, sob o comodismo de não agir. Precisamos de reinventar a nossa consciência, pessoal e coletiva, para que, ao alterarmos a nossa forma de agir, consigamos de facto alcançar uma sociedade sustentável. Como disse Chico Buarque, a

6 É a capacidade de perceber o próximo, fazendo-o sentir que está a ser compreendido, e que existe uma forte empatia, correspondida, no laço estabelecido entre as duas partes. 
sociedade é que deve se aperfeiçoar por uma dinâmica própria, de baixo pra cima, com a participação da grande massa de indivíduos, certo? Quer dizer, o homem modificando a sociedade para a sociedade modificar o homem (Buarque, 1976, citado por Martins, 2005, p.6)

Para finalizar, a canção "Construção" de Chico Buarque, que remete para a necessária ecologização das relações sociais, entrecruza as vertente social, económica, ambiental e de governança, e, tal como refere Diamond (2008), citado por Goleman (2009, p. 247), guarnece a sociedade de força e incentivo para (...) parar de falar que é preciso curar a terra (...). A Terra não precisa de cura. Nós, $\operatorname{sim}^{7}$. De facto, nós é que precisamos do tratamento. É essencial que mudemos os tijolos que constroem a nossa realidade, para que no fim não nos sintamos apenas mais um pacote bêbado a atrapalhar o sábado do planeta. Não percamos a sabedoria para construirmos o nosso futuro, para o tornarmos possível. É isso que torna os nossos comportamentos sustentáveis.

\section{REFERÊNCIAS BIBLIOGRÁFICAS}

ALMEIDA, Miguel. Marialvismo: a moral discourse in the Portuguese transition to modernity. Série Antropologia, 184. Brasília: Departamento de Antropologia, Universidade de Brasília, 1995.

BAUDRILLARD, Jean. A sociedade de consumo. Trad. bras. de Artur Mourão. Rio de Janeiro: Elfos, 1995. BRUNDTLAND, Gro. Our Common Future. Report of the World Commission on Environment and Development, transmitted to the General Assembly as an Annex to document A/42/427 Development and International Cooperation: Environment. Oxford University Press. 245p., 1987. Disponível em http://conspect.nl/pdf/Our_Common_Future-Brundtland_Report_1987.pdf. Acedido em 3 de janeiro de 2013.

BUARQUE, Chico. Construção. Polygram. CD, Faixa 04, n. 836013-2, São Paulo, 1971.

BUARQUE, Chico. $\quad$ Revista $365, \quad 1976 . \quad$ Disponível $\quad \mathrm{em}$ http://www.chicobuarque.com.br/texto/mestre.asp?pg=entrevistas/entre_365_76.htm. Acedido em 28 de fevereiro de 2013.

FERNANDES, Rinaldo. Chico Buarque do Brasil: textos sobre as canções, o teatro e a ficção de um artista brasileiro. Rio de Janeiro: Garamond, pp. 25-26, 2004.

GOLEMAN, Daniel. Ecological intelligence: how knowing the hidden impacts of what we buy can change everything. New York: Broadway Books, 2009.

GOLEMAN, Daniel. Emotional Intelligence: Why It Can Matter More Than IQ. London: Bloomsbury, 1996.

GOLEMAN, Daniel. Social Intelligence: The New Science of Social Relationships. New York: Bantam Books, 2006.

KUTTING, Gabriela. Globalization and the Environment: Greening Global Political Economy. Albany: State University of New York Press, 2004.

MARTINS, Christian. O Inconformismo Social no Discurso de Chico Buarque. Fênix - Revista de História e Estudos Culturais, Vol.2, Ano II, n. 2 (abril/ maio/ junho), pp. 1-18, 2005. ISSN: 1807-6971. Disponível em http://www.revistafenix.pro.br/PDF3/Artigo\%20Christian\%20Alves\%20Martins.pdf. Acedido em fevereiro de 2013.

MARTINS, Christian. O Inconformismo Social no Discurso de Chico Buarque. Revista de Revista de História e Estudos Sociais, Uberlândia, v.2, n. 2, p. 1-18, 2005.

MENESES, Adélia. Chico Buarque de Hollanda: Literatura Comentada. São Paulo: Abril Educação, 1980. MENESES, Adélia. Desenho Mágico: Poesia e Política em Chico Buarque. São Paulo: Ateliê Editorial, 1982.

MORAL, Roger; WALKER, Lawrence. Environmental disasters, natural recovery and human responses. Cambridge: Cambridge University Press, 2009. DOI:http://dx.doi.org/10.1017/CBO9780511541995.

7 Texto original: We have to stop speaking about the Earth being in need of healing (...). The Earth doesn't need healing. We do. 
RIBEIRO, Maurício. Ecologizar. 4ª ed. Vol. II e III. Brasília: Universa, 2009.

RIDENTI, Marcelo. Em busca do povo brasileiro. Rio de Janeiro: Record, 2000.

SÁ, Luís de. Introdução à Ciência Política. Lisboa: Universidade Aberta, 1999.

SASSA, Kyoji; CANUTI, Paolo. Landslides - disaster risk reduction. Berlin/Heidelberg: Springer, 2009.

SKIDMORE, Thomas. Uma História do Brasil. São Paulo: Editora Paz e Terra, 1998.

SMITH, Eliot; MACKIE, Diane. Social psychology. New York: Worth Publishers, 1995.

STONE, Michael. Smart by Nature: Schooling for Sustainability. Healdsburg CA: Watershed Media, 2009.

UNAMUNO, Miguel. Do sentimento trágico da vida. Trad. port. de Artur Guerra. Lisboa: Círculo de Eleitores, 1989.

VIANA, Hermano. O Mistério do Samba. Rio de Janeiro: Jorge Zahar Editores/Editora da UFRJ, 2004 [1995].

WEBER, Max. A Ética Protestante e o Espírito do Capitalismo. 4ª Ed, Lisboa: Presença, 1996. 
